\title{
ROD STEWART IS EVERYWHERE
}

There he is, frowning into the pores of an orange outside my corner deli. The only thing I can factually say of him is that we've either met or seen each other before, perhaps multiple times, though in what capacity I can't recall.

But this is my commute to work, and it's cold, even for February. I walk onward, just behind two women buried in fine furs. One says to the other, "That's Rod Stewart," and the other squeals under her breath, but I still can't place the man. I spare a look back, but Rod Stewart has gone, presumably into the store to purchase oranges. Taped to the door of the deli are four paper hearts, crookedly cut.

The Daily Uproar: rumors of an amendment to tax law 114-877-3C regarding independent business owners in mid-proximity to Class-4 Acts of God. I send Stein off for precedent checks, and she bounds admirably across the office, bob cut bouncing. Chapin snails his way through the disaster log, and Dresher pretends to know how to read loss modules. This is my staff.

But it is I who render useless their efforts by calling to mind the strange case of Lesterville Meats, the only company in Lesterville County to survive a brutal tornado in fiscal '76. By lunch I've constructed two Loophole Packages, which Stein helps me explain to Chapin and Dresher over turkey sandwiches. Should the amendment pass, twenty-eight of our top-tier clients will be windfall-bound. Not an inconsequential day for our department.

In high spirits after lunch, I call Dresher into my office to ask what he makes of the name Rod Stewart. Dresher beams at this rare chance to be of use.

"I believe he was the host of The Twilight Zone, sir."

"And what does that mean to people? Twilight Zone?"

"It's a television show from...I want to say the early fifties?"

"Was the program hosted by a child, Dresher?"

"No, a man. Mid-thirties, perhaps? I'm pretty sure he's dead."

"Dresher, this Rod Stewart isn't dead, nor is he old enough to have hosted a half-century-old show."

"Oh!" he bellows, laughing, jiggling. "I thought you said Serling, sir."

"I did not. Shall I repeat my question?" 
Dresher stops chuckling and wipes his brow on his cuff.

"He's a singer, sir. He wrote the 'Do You Think I'm Sexy' song."

"The...?"

“'Do You Think I'm Sexy.' It's a song, sir."

"A singer, then. Thank you, Dresher. That'll do."

He plods from my office.

On my way home, I see Rod Stewart again, leading a leashed Pomeranian across Broadway and Liberty. I'm unsurprised to find that he is a keen whistler, given the fact that he sings. The dog seems fond of him.

Rod Stewart turns right on Broadway and heads north. I'm forced to follow him and his Pom. He turns left when I need to turn left, and right when I need to turn right. Not wishing for him to believe I am in pursuit, I cross the street and take a longer route to the deli for my turkey sandwich.

$\mathrm{He}$ is in line when I arrive. Why would Rod Stewart-a singer famous enough for me, of all people, to name on sight—buy a sandwich at my deli? Surely there exists an entire city's worth of eateries better suited to his wealth and notoriety, no? Why endure such narrow aisles, the surly Arabs who make the sandwiches, or the dusty reek of expired sundries? Why today? And yet he is here, taking his sandwich to the counter for purchase, with me standing dumbly in his path. I move left to let him by, but he moves right. When I move to accommodate, he does the same, so I turn my back and flatten my body face-first into a tall tower of chips. His breath briefly tousles the finest hairs on my neck as he passes without offering thanks. The man behind the counter nods and wordlessly turns to assemble my turkey sandwich.

But in the time it takes me to claim my dinner and step outside, Rod Stewart is still there, his dog having only just finished urinating on a parking meter. I'm left to follow them for several more blocks before Rod Stewart glances back at the exact moment I glance at him. Feeling more than a bit flustered, I turn down a succession of unrecognizable side streets, until I'm nearly four blocks from my usual route, and I hear him whistle that same tune.

He and his hound emerge from the shadows of Barclay Street on my left. I make a long loop around City Hall Park, but we meet again and do not part until I reach my apartment and he enters the building directly opposite. I bolt past the night doorman, into the elevator, up to my unit. Leaving the lights off, I creep to the window, not entirely sure what I expect to see, or why it 
is worth my time to lurk like this. I've done nothing wrong, and surely there is no possibility of spotting him in the huge grid of windows across from my own. Then the penthouse lights burst from a stone cupola atop the building. A door slides open onto a balcony, and he steps into the cold, not two hundred feet away. He places both hands on the rail. He whistles.

I see him every day for a week, and then another, right into March. I follow him to work and I follow him home. In further defiance of his own stature, he now frequents my deli. It grows awkward; perhaps I should greet him or at least nod in his direction, if only to recognize the increasingly staggering odds we somehow continue to conquer. Perhaps all of this can become a trifle at which we are one day able to laugh.

The amendment to tax law 114-877-3C regarding deductibles for independent business owners in mid-proximity to Class-4 Acts of God is officially announced and generally favored to pass at the next congressional session. Stein bursts into my office to scream the news, and Mr. Percy puts in a rare appearance. I have worked at Percy, Abramowitz, and Kobayashi for nearly nineteen years, long enough to know that Mr. Percy only descends upon the office when something has gone wonderfully right or horribly wrong. Today he comes bearing firm handshakes and a bottle of champagne.

"You still got it, champ," he says, pouring. "Don't let anybody sell you short. Who cares how long it's been since you pulled a saver like this-you're still the great gazoo of high finance. How much are the slaves calling it?"

"Ten to fifteen," I say, producing the projection sheet, "depending on whether the amendment passes. Plus, they'll have to extend the legal definition of mid-proximity to ..."

"Ten to fifteen million," repeats Percy and whistles over at my staff, who always seem faintly intimidated by him; Mr. Percy has a tendency to speak from the very back of his lungs. Even the smallest trivialities come out sounding sermonized.

"Say," he says, "I ever tell you three about how your supervisor here sealed the Evans case in-what was it?-'92?"

He tells it. I won't repeat it here, but Mr. Percy belts it like a song, and by the end of it, Chapin, overcome with emotion and a glass or three of company champagne, opens his arms for a hug and advances. I step back in panic, and a steel mesh wastebasket topples over with a clang. Chapin blushes and puts out his hand for a shake. I accept and attempt to offer him an expres- 
sion that says you're a slightly above-average employee, Chapin, but there will be no embracing in my department. He stoops to attend to the wastebasket.

Then Stein and Dresher want their own handshakes, so I oblige and try to provide for each of them a uniquely communicative expression.

I give Stein a look that says you've performed admirably, as usual, Stein, and you'll have my chair once I've made partner, but you haven't yet got the stomach for post-divorce cases, a vital skill at a firm with such a fast-growing roster of celebrity clients.

To Dresher, my look says I wouldn't be surprised to find you axed within three months, once I've accumulated enough of your abysmal performance evaluations to justify termination. Plus, you could stand to lose between twenty-five and thirty-five pounds, and I don't see why you refuse to cut your hair with some semblance of regularity. It's disgusting. You disgust me, Dresher, and you will never even begin to comprehend the importance of order in this field.

"Thank you, Mr. Klangert," says Dresher.

Perhaps the rare glass of champagne has flown my flag a bit high, but when I pass Rod Stewart on my shortcut through Cedar Street, I smile with plenty of teeth. I intend this smile to salute the inscrutable engines of chance. The numbers. I wish my expression to say what is one to do with all this?

Rod Stewart responds with a look, which presently becomes a stare, then a study, and then a barely perceivable frown. I take the opportunity to stare back at him, stubbornly smiling. In this way, I learn that Rod Stewart is morosely unattractive. He looks as if he's only just been in a horrible car crash while simultaneously suffering a stroke. Ugly, ugly old man, and he's frowning at me still, but only the slightest bit, as if I'm not worth a fully certified frown. I commit desperately-pleadingly - to smiling, even at the exact moment we pass each other, eyes locked until our necks can twist no further. Our combined smells toss around in the air between us and it's over.

Unsettled but still refusing to stop smiling, I hurry on down Cedar Street, which plays host to the eeriest echoes in lower Manhattan. The resonance of my footsteps, my breath, glance off the walls and return to me changed, like something recorded and played back.

But everything is fine. Even though the amendment to tax law 114-877-3C regarding deductibles for independent business owners in mid-proximity to 
Class-4 Acts of God has stalled around an unreasonable redefinition of "midproximity," a new plan is afoot, and the department is almost making quota.

Plus, Rod Stewart and I have tacitly agreed to ignore one another, through a snub competition. I am new to snubbing, but I've quickly learned that to win at snubbery is in no way a simple feat. The objective is to ignore your opponent to a greater extent than that to which he or she ignores you. Rod Stewart and I end mostly in draws; we notice each other and flick our eyes awkwardly away.

Today, I snub him on my way to work by pretending to read a bus stop schedule just before he makes eye contact, a capital snub. But on the way home, I see him arise from a subway entrance, the last place I would ever expect to see him, and in shock I drop my BlackBerry on the concrete. He doesn't so much as glance at me as I crouch to attend to the parts of my phone. His Bruno Maglis approach and make an exaggerated semicircle around me, as if to avoid stepping on something unpleasant.

From that moment onward, I keep affixed to my face an expression of snub-readiness at all times. It is like lugging around a gun loaded only with disdain. I begin to ignore absolutely anyone in my periphery, plus I can't wipe away from my face a snub-ready frown, which I discover in my reflection of a Starbucks window is the exact frown he wielded at me last month on Cedar Street. My work suffers; it is tax season. I have sufficient difficulty keeping my patience with Dresher and explaining things tenderly enough to keep from making Chapin cry without this vague disapproval etched into my features.

More importantly, I keep a trimmed regimen, to say the very least. There are no cracks in the schedule I've spent years perfecting. Even the walk to work is imperative; nothing steels the mind so completely as a twenty-nineminute commute through the elements, alone. It is for this reason, perhaps, that the simplest solution eludes me for several weeks: simply rise and retire fifteen minutes later than usual every day. It would mean the end of my fifteen-minute safety buffer, but if this has indeed become a territorial dispute, perhaps it is time to make the necessary concessions.

I try it the very next morning, and it is gloriously like a cease-fire, with Rod Stewart nowhere to be found for the first time in six weeks. The air has taken on the floral chill of an early spring through which I walk alone, free to experience my environs, without the censure of broken probability. So cleansing. A smile reaffixes itself to my face all the way to work, where I notice that I 
am-for the first time-nearly late, so I dash into the elevator just before the doors clamp shut.

I smell him before I see him next to me, the smell of freshly washed hair wafting from him. I press 12, just under his 14, and we stare silently up at the numbers, in a snub-stalemate.

And then he speaks.

"We've been seeing quite a lot of each other lately, haven't we, mate?"

I'm surprised to find that he's English, and that we're finally ready to talk this out.

"I'm so relieved you brought it up. I was beginning to think you didn't notice me."

Rod Stewart swallows, says nothing. "No, I didn't mean... it wasn't so much that I wanted you to notice me. Not at all. I am as baffled by this... connection we seem to..."

Rod Stewart reaches out and jabs the button for the next floor, number 9. "We. Do not. Have a connection."

"Of course I didn't mean...I'm only trying to point out the enormity of what's happening. We have randomly encountered one another-what is itforty, fifty times? And let it be said that the only time I ever spend in public is the twenty-nine minutes it takes to get to work and back, plus a ten-minute buffer in which to get my turkey sandwich."

The elevator stops and holds, but I speak onward, helpless to stop the words brimming out of me. "That's fifty-eight to sixty-eight minutes per day, five days a week, plus anywhere from twenty to sixty minutes over the weekend. Does this not astound you?"

The doors part, allowing Rod Stewart to back slowly away, and then shut, cleaving us from one another. The things I've said to him hang so heavily in the air they are nearly tangible, like something you could pocket.

The next morning, I wake up to a strategy I must have dreamt of. Instead of simply snubbing him, I should cross the street or run away outright, really open up some distance between us. Thus begins the phase of instant retreat. I leave fifteen minutes early in sneakers and keep my pace at a mild jog, a readiness. At any sign of him whatsoever, I dart. The look on Dresher's face when he sees me in sneakers is almost worth the effort.

After several weeks of this, I spot a sign of him in the distance: a gauzy, jaguar-spotted hybrid of scarf and cape, Rod Stewart's gypsy flag, the one 
he wears only on windy days when he can be sure it will billow, and I bolt clear over to Church Street, laughing with surprise at how fast I can run-I'd forgotten what the treadmill was actually for. And then Rod Stewart rounds the corner ahead, and after I swerve to miss him, there is suddenly such rage inside of me.

"Impossible!" I scream. "Outright! I saw you more than five blocks ago! Unconditionally impossible!" But he just moves away from me at what can best be described as a wary trot. "Fuck you, Rod Stewart!" I call after him.

I hadn't counted on the glee of releasing that off-color bit of froth: fuck. I'd avoided the word altogether, so as to stay in compliance with Belle over at Human Resources, but it really is an astounding, peerless little word. Belle, by the way, is a fan of Rod Stewart. I never before took the time to notice. She quotes him at the tail ends of her e-mails, posts pictures of him all around the office; so he is there as well, always.

Several days later, I receive a summons in the mail to appear at small claims court to contest Mr. Stewart's application for a restraining order on June 2oth, one month from now. It is only then that I realize-reading and rereading the cold, legal typeface - that a man who bolts every time he sees someone doesn't necessarily appear to be in full control of his faculties. This abruptly halts the phase of instant retreat. But what other recourse exists? A restraining order from either of us is useless. I'm not sure it's possible to keep him at bay by a mile, a half-mile, or even several dozen feet.

I set the letter down and try not to tremble, but the slow, sinking feeling of things going irreparably wrong plagues me from the gut up, and I run for the master bathroom to disgorge.

That night I dream of him.

The next day I seek him. It is time to confront this. It should prove no difficult task to exhibit to him the entanglement of our lives and to convince him that the only recourse left is to work out some sort of time-share. The key is to approach him with my hands high in the air in total, abject surrender. He'll no doubt mistrust my intentions at first, but I'll write up a sign proclaiming my harmlessness. Once I explain to him my route, my schedule, and where I'll be from moment to moment, he'll finally be able to see that all this can be avoided, or at the very least that I am hardly a threat. 
I exit my building and scan the streets for any sign of his clothing, his hair, or his dog, but there is none. Of course! Now that I am actually seeking him, he is nowhere to be found! It is such a simple, if baffling, solution, until I spot him sucking out the last droplets from a blue-tinted bottle of water. I put my arms up and produce a sign that reads PLEASE DON'T FEAR ME, ROD STEWART and at the same moment notice that his Pomeranian has been replaced by an enormous, pale bodyguard.

His name is Milosz. I know because he refers to himself in the third person as he pursues me down Broadway. "Milosz come to get you, my friend" and "Milosz make it jelly out of you" and after ten blocks, jogging to a full, panting stop, "You watch for Milosz. He meets you someday."

Thus begins the phase of disguises.

My clock radio alarm goes off and he is there.

I wake up and open my window and he is there.

I don a baseball cap and a London Fog trench coat, despite the fact that it's May. I tried to buy a wig but he was there.

I wish it were raining, if only for the muted light and cover it would provide.

I opt to navigate the smallest and most crowded of Manhattan's lower stretches, Broad Street, New Street, Maiden Lane, Pearl.

In the Thames Street alley between Broadway and Trinity, I spot them. I double back and head south, but there they are three blocks later, both panting, as if they've run to intercept me. I follow them carefully to the office, both of them glancing occasionally back. And I begin to hate Rod Stewart increasingly, with every glance, and with good reason; he must somehow be responsible for this. Of course! The frequency with which we encounter one another is impossible without Rod Stewart's own design, but at that moment Milosz narrows his eyes at me, and again I run the rest of the way to work, the ridiculous sign crumpled in my arms.

The amendment to tax law 114-877-3C regarding deductibles for independent business owners in mid-proximity to Class-4 Acts of God has failed to pass. My staff is crushed, although I suspect that Dresher is merely pretending to understand. Stein, soldier that she is, takes it particularly hard and wastes much of the day squinting up at the overhead hum of the fluorescent lights. We've lost a projected gain of almost fourteen million dollars. I wait all day for Mr. Percy to descend, but he refrains. 
Honestly? It requires effort to commiserate. I can't stop dreading my next brush with Rod Stewart. Will he call the police, perhaps? Will he become suddenly violent? The British are notorious for hooliganism, are they not?

Just as my staff is preparing to leave for the day, Stein hesitates.

"Actually, sir? Would you like to join us for drinks?"

Chapin and Dresher freeze in the midst of putting on parkas and stare into each other's eyes. I don't wish to disappoint them, but this is a perfect night to research overseas expansion incentives, and there's still the matter of my daily double-check. Then again, perhaps if I am in the presence of others, I'll avoid seeing Him. I don't really have any friends, so this could present me with a rare opportunity for evasion.

"My answer is yes. But it must be a bar I know twenty-seven minutes from here, near my apartment. Is that acceptable?"

Dresher and Chapin frown at one another.

"I...," says Dresher, "jeez, twenty-seven, did you say? I think Ed and me, we have to go someplace a bit closer."

"Yes," says Chapin, "that's true."

"I completely understand," I say.

"I'll join you, sir," says Stein.

It turns out that what I thought was a bar near my building is actually the neighborhood pizza purveyor, so Stein takes us to a nearby lounge. I tend to avoid rooms ridden with drunks, but Stein seems quite the veteran. She couldn't be more than five-foot-two, yet she manages to procure a pair of enormous green drinks with limes in them from the scariest bartender in the room and then beckons me through the thick of braying patrons. It proves difficult to hold my daunting drink and my briefcase while also plugging my ears. Stein selects a table in front of a row of windows and next to a side door. She tosses aside a sign that reads RESERVED and raises her glass into candlelight.

"Well, Mr. Klangert," she says, "it was a fine Loophole Package."

We touch glasses, and Stein treats herself to a series of long, steady gulps; her throat bulges like a snake digesting a small, unfortunate animal. I manage a few furtive sips, but the drink tastes too strongly of alcohol, and yet when she sets the glass down, it's nearly half finished. Her coffee-and-creamcolored face begins to redden. 
"Not once in the six years we've been working together would I have envisioned you as a bar person, Stein."

"I don't know that I'd call myself a bar person," she says, chewing on a thin, red straw, "but after a hard day you have to make life livable again. And what about you, Mr. Klangert? How do you make life livable? You obviously exercise, right?"

"Yes, I have a treadmill, but outside of work I do the same essential things I do at the firm. Nothing else, really. I keep ants."

"Like in an ant farm, or...?"

"In a formicarium, yes."

"That's so perfect."

"Why?"

"Because. Of course you have an ant farm."

She takes another heroic sip and leans back in her chair. I have no idea how she can drink like this. I already feel slightly adrift but strangely comfortable here with Stein.

"The guys would love that. I suppose I shouldn't say this, but... well, I won't say who, but either Chapin or Dresher calls you pathologically productive."

Maybe it's the drink with limes, but my comfort gives way to a pang of hurt.

"Pathologically? As in 'disturbed'? Do they find me somehow imbalanced?"

"No way," she says, laughing sharply. "Imbalanced' is about the last word I'd use to describe you."

The pang of hurt remains.

"Was it Dresher?" I ask. "He's too idiotic to take seriously."

I can't believe I've just said this-out of hurt feelings! - to a subordinate, and begin thinking up my defense, different phrasings, some choice snippets of his evaluations to quote to poor effect, but Stein surprises me.

"Oh, dear, sweet Jesus, I know. Poor, dumb Dresher."

"Stein! I can't believe you feel the same! I thought it was only me!"

"No, are you kidding? How he screwed up the deferment package for Farber and Sons is beyond me. I have nightmares about that one."

"I do as well!"

We laugh loudly together, and it feels fantastic to hear my laughter in concert with hers. 
"Sir? I have to tell you something. I just...I love your work. You may not put up the top savers, but your correlations... well, they're poetry. I mean that. I wanted you to know. And I think it's shameful that Mr. Percy steals all the credit."

Feeling a bit disappointed that we're through with laughing, I say, "Stein, that's ridiculous. A brain is nothing without a face, and that face is Mr. Percy. I may have the ideas, but Percy renders them scrutable. He makes them seem glamorous to even the most dimwitted clients."

"Of course I didn't mean to slight him. I know how well you work together, and he obviously respects you. Isn't it true that you're the only non-partner with a key to the company yacht? I hear it's amazing."

"Oh, I don't get out to The Sea PA as often as I should."

"Is it true that Mr. Kobayashi shoots clay pigeons from the bow?"

"I really wouldn't know, Stein. Actually, I quite embarrassed myself the last time I joined them. I just didn't have much to say once they banned office talk. I'd prepared so completely to discuss business, but I wasn't prepared for..."

Stein points abruptly at my right ear. She then sweeps her finger horizontally across my face. At first I assume she is performing some sort of ritual. It takes me another moment to realize she is not pointing at me but at the windows behind me, and of course I don't have to look to know who's walking past them, who's approaching the side door and then stepping inside. Stein opens her mouth, and I know what she's going to say, I could mouth the words along with her, so I do.

"There's Rod Stewart," I say, but she says, "It's Rod Stewart," which is contextually less precise, as it fails to take into account his proximity. The shadow of Rod Stewart drapes itself over our table, our candle, but I don't turn to face him.

"Pardon," he says, "but this table's reserved."

I head home with Stein drunkenly in tow, her eyes glazed and green. Thousands of pollen wisps drift through the air, settle on the ground like snow.

"This is where I live," I tell her.

"Oh, okay," she says and laughs, and I join in so that we'll both be laughing again, but then she stops, and we observe a growing silence. And in 
that silence, I sense that she is waiting for me to say something. Something specific.

"Is there anything I can do for you?" I say.

"Um, wow. Not really, I guess. So I'll just... head home, then?"

"Excellent. See you tomorrow, Stein. You're the best I've got."

I had assumed this would appease her, but she merely mumbles something and waves over a cab. And still, I sense it hanging there unsaid, so I call after her. She turns back, halfway into the taxi, with an expectant smile.

"There's," I tell her.

She stops smiling.

"What?"

“The more precise way to say it would have been, 'There's Rod Stewart,' not 'It's Rod Stewart,' given the context."

There is a moment. Stein looks into the headlights of an oncoming car.

"Yes, sir," she says, then finishes getting into the cab as the oncoming car pulls up to Rod Stewart's building (a silhouette of jagged hair), and I jingle out my keys, creep inside.

This week, I put Stein in charge and begin my research. I send Dresher to the library for biographies. I peruse the Internet for photographs, interviews. I note that He first fled England for tax reasons. I download songs and their lyrics and find them plebian, terrible, and that voice. The rasp and gurgle of that voice like the last words of an old woman being choked to death. And his hair, apparently his signature-but has no one ever observed that he is simultaneously sporting the hairstyles of at least three people, Frankensteined to different parts of his scalp?

Conversely, the biographies speak of a Rod Stewart active in Amnesty International, a father of seven, a man who overcame thyroid cancer and retrained himself to sing. He doesn't seem at all the type of person to insist himself into my life with such malicious regularity. Surely no one in the world has either the time or the inclination to ruin so intricately the life of someone else, and even if they did, why me? I was born an orphan, I've spent the bulk of my years working harder and more efficiently than everyone else, I don't smoke or socialize, and I rarely drink. I've never stolen a thing, not so much as a grape in a grocery store.

And yet: Rod Stewart stepping into Duane Reade. Rod Stewart holding hands with a dirty-haired little girl. Rod Stewart dressed for a party on 
an overhead balcony, ducking when he sees me. Rod Stewart eating fleshcolored yogurt in the park with no name. Rod Stewart riding past the company picnic on horseback. Rod Stewart imagined on my sofa or sitting at my desk, or the bulge of his body as he sleeps in my bed. Rod Stewart cursing through clenched teeth at a taxi that comes so delicately close to hitting him, I scream when it misses and Milosz almost sees me. And Rod Stewart in my dreams, Rod Stewart ninety-three stories tall and towering over Manhattan, his personal formicarium, attended to by swarms of bodyguards, Rod Stewart stomping buildings into ragged shells, and in every fiery footprint he leaves in his wake, a war begins, and how can this possibly worsen, where can this possibly lead? Rod Stewart in my building, my unit, my bedroom, my office, everywhere, Rod Stewart absolutely everywhere.

Perhaps this is what stalkers really are. People who want nothing more than to break out, to get away, but only prison provides that escape. I consult the Internet for other accounts of this phenomenon. There are none. I probe Rod Stewart's life for precedents. There are none. I start combing his lyrics for clues. There are none, and then Mr. Percy steps into my office after a cursory knock.

"Hey, pal," he says, "see the game?"

"Which? Well, no."

"Oh?" he says and walks around my office, my degree from Northwestern, my whiteboards. He draws a deep breath into his huge frame.

"Listen, we need to talk," he says, gravely exhaling. "You know Randy Newman's a client, yeah? Well, he told me at lunch... he says that you're stalking Rod Stewart, and I'm the guy they sent to ask if that happens to be true."

"No, it's not."

"Okay. But I'm forced to notice that you hardly seem as surprised as I'd expect from a man being accused-not that I'm accusing you-of stalking someone. So I'm left to give the question a second go-round. Are you stalking Rod Stewart?"

"No, sir, I am not stalking Rod Stewart."

"Hey, good enough for me. But Dresher-is that his name?-says you sent him to the library for a stack of biographies, and also I'm seeing a... well, frankly, Klangert, I'm seeing an alarming number of pictures and-are these 'Maggie May' lyrics? - littering your desk. And does that sign say 'Rod Stewart, please don't feed me'?” 
"Fear me. I thought... he'd make a good client. Given his past tax evasion."

"Irrefutable. But that's really more my job than yours, so lemme go ahead and pose the issue from a new angle. Is Rod Stewart currently pursuing a legally binding order of restraint against you?"

I fumble for ways to avoid saying yes. There are none.

"Yes. But it's his fault."

"His fault? Let's break that down together; you first."

"It's quite complicated, Mr. Percy, but you must believe me. I'm innocent."

"Of course you are, Klangert. And no one's saying otherwise. But does he have a case?"

"He...yes."

"Would you characterize his case as strong?"

"Yes," I say, but when Mr. Percy says nothing, I can no longer restrain myself from expanding, tentatively at first, and then with unreserved anger and desperation. I tell him of the oranges, my deli, my commute, and of Milosz. It feels fantastic to unburden myself, to share the pain of it with someone I know as well as Bill Percy.

When I finally feel myself starting to wind down, he closes his eyes and hunches forward in his chair, squeezing his temples between his thumbs and middle fingers.

"Klangert," he says, and the room suddenly seems so quiet. He lifts his head and looks at my left eye, then my right. "We're prepared to offer you a full year of severance."

Never in my life has anything changed so quickly, and yet my brain has already begun to account. The stapler is mine, the books are mine, the desk is the firm's, the seat-pillow is mine. The ensuing silence confuses me for a few moments, until it becomes clear that Mr. Percy expects me to thank him. Well, I refuse. I absolutely refuse to give thanks to this man who sides immediately with Rod Stewart and Randy Newman after countless hours of service and millions of dollars saved, millions of them. But the silence grows unbearably immense, so I compromise.

"That's more generous than I expected."

Mr. Percy smiles grimly.

"You're welcome, champ."

Why give Rod Stewart the satisfaction of encountering me just after I've been fired? Throughout this entire ordeal, I've avoided breaking my routine out of 
stubborn duty, but now that Mr. Percy has ended my career, I decide to take a taxi home.

Of course we end up tailing Rod Stewart, and of course Milosz notices, and yes of course we stop at a red light long enough to allow Milosz to exit the car, crack his knuckles, and approach my cab, and of course there is nothing to do but bolt yet again, shouting why today, why take a taxi today, of all the days you could have, why today, Rod Stewart, why today?

Without work, there is no need for time. I stay home as often as possible. I nail cardboard over the windows and throw myself into solving the riddle of Rod Stewart, but what riddle? Where does one look? Neither his life nor his music gives any indication of culpability. I've approached the same materials so many times, with no positive results. I could attempt to get my hands on his garbage or mail, but the outcome of such a pursuit seems easy enough to predict and would negatively affect my deposition.

So I begin to appraise the material differently. I try reading every other word of his biographies, every fourth word. It dawns on me that there exists the possibility that Rod Stewart and I have been linked for some time, for years even, but I only began to notice back in February, when I knew only that I'd seen him somewhere before, a blissful time.

Playing our encounters over in my mind, I remember him pressing number 9 in the elevator, and I begin cutting up his lyrics into nine-word clusters and reassembling them randomly:

I Am Sailing Stormy Waters to Be Near You

For Parting Is Never Good-bye We Will Be Together

Want You by My Side Just to Help Me

I See Sweet Oh Sweet Surrender, Sweet, Sweet, Surrender

Just Reach Out and Touch Me Come On Sugar, and it is this last line that sparks a possibility. What if I were to simply reach out and touch him? Would this all come to an end? Is it not as viable a solution as any other? I decide to try it immediately, but the instant I exit the building, Milosz steps out from behind a parked car, grabs me by the throat. I choke on my own breath as he throws me to the ground.

I have never before been beaten. At first I try to block his blows, but in the rain of fists that follows, it becomes impossible to isolate one from the next, except as a confusing, all-encompassing hurt. I resign myself to pleading with Milosz, screaming why is he doing this, did he send you, beat me if you must but I'm 
begging you, I'm begging you, Milosz, to please please please just tell me why he's doing this I'll pay you whatever you wish only tell me why he's doing this, why me? But I have no idea if it comes out coherently. Still, he's the closest thing I have to Rod Stewart, so I beg and I beg until something in my jaw snaps and flashes, causing my words to taste of live electricity and blood.

"Rod 'retrains' you," growls Milosz, and gives my ribs a parting kick before leaving me to a roaring silence. I wish he'd kill me. I'd beg him to do as much if I could move my jaw. My career is over, my life is filled with nothing but Rod Stewart, and once he gets his restraining order, I'll be at his mercy until I go to prison, real prison, not just for tax gurus.

And then-just before succumbing to unconsciousness-inspiration: if he really wants me restrained, he'll have to be in small claims court, or the case will be thrown out. Which means that as of nine a.m. a week from today, I will know exactly where Rod Stewart is for the five to ten minutes it will take the involved parties to realize I won't be in attendance. It isn't much, but it's enough time to constitute a head start of sorts. I start to smile, but the pain is unbearable, and I succumb to exhausted blackness as the doorman makes his tentative approach.

The clock radio plays "Young Turks" at the first light of the twentieth. I creep into the living room and remove a square of cardboard from the window. He emerges from his building at 8:45 in a tailored suit. He puts up his hand for a cab. He drives away, Milosz nowhere in sight.

I shatter my bathroom mirror with a broom handle, take a shard of it downstairs, and poke it out of the service entrance to check for signs of Milosz. There are none.

I grab my suitcase and creep out the entrance into an early morning chill. The iron door booms closed behind me. It is 8:50. I flag down a cab and climb inside. It is at this moment that I remember that my shattered jaw has been wired shut. It's been that long since I've spoken to anyone.

"North Cove Marina," I say, but it comes out "Note Comb Maweena."

The driver doesn't even speak, just shrugs with maddening nonchalance.

I enunciate, but the effort is painful: "Note. Comb. Maweena."

He shrugs again. It is 8:52. I begin screaming it through flashes of pain, Note Comb Maweenah, Note Comb Maweenah, waving my shiny shard of glass in the air, and then he is suddenly screaming indecipherably, so I leap out of the cab. The screaming has taken its painful toll; dizziness leads my feet 
astray. I rally myself to stay the course, don't pass out, don't succumb, there's a pen in your pocket, just get paper, Klangert, my boy, just get paper, and I limp over to The Family Dollar, my vision gauzy and crooked and then threatening blackness, so I lean against the bricks and breathe. I recover at 8:55. A child points to me and laughs.

In the store I realize I've forgotten my suitcase in the taxi and subsequently have no money, which is perhaps moot because I can't find any paper. It is 8:57. I grab a box of envelopes and walk out of the store, my first theft ever. Once outside, I write NORTH COVE MARINA in big black letters. A police car drives by, sirens screaming. It is 9:02. The defendant has failed to appear.

The next cab driver I flag down says nothing in response to my makeshift sign or imploring expression. He just puts the car in gear and drives. The relief that courses through me is like nourishment. I close my eyes to better relish the sensation. I put my head between my knees as if preparing for a plane crash. I bury myself here in the backseat to avoid seeing him or anyone else.

"Escuse me?" says the driver. I lift my head. The driver's eyes look concerned in the rearview mirror. He holds up an $\mathrm{O}$ between his thumb and forefinger. "Okeh?"

That is when I cry. It just happens, I don't know. I do know that I want more than anything to tell him how much his basic human kindness means to me. I want him to know what he has done for me, for the rest of his life he deserves to know. I consider writing it down, but what would I say? Instead, I make an okay sign back at him, and at 9:04, when we pull up to the marina, I hand him my London Fog coat and run for the docks.

I'm prepared for any number of potential scenarios at the security gate, but the guard merely checks my ID and waves me onward, toward the company slip and the sea.

I cannot recall with any accuracy the details regarding my departure. I remember plenty of laughing through tears, or maybe that was merely surf. I remember bashing into boats on my way out of the dock: Tranquility, Rebecca's Present, The Mrs. Unguentine. I remember unbelievable speed, wind, and a sense of victory, even after The Sea PA sputtered and stopped out here on the Atlantic, not a spot of land in sight. And now there is only the sea, as gray and wrinkled as the skin of an elephant, under a bright white sky. It is how 
I'd always envisioned purgatory. I don't know how many days I've been out here, or how much water is left. I grow weary of cold canned food.

Other than that, it is not altogether a horrible end to my life, such as it was. The Sea PA (my second and final theft) is a fine, fine vessel, and out here, Rod Stewart is nowhere to be found, except for hints of his voice in the cries of dying seagulls. Without a schedule to keep, I am mostly left to think. Of where precisely things went wrong, what I could have done differently. I think of my career, and of Mr. Percy and how Stein may have been right about him stealing credit from me.

Regarding Stein, I've come to believe that she wanted me to disrupt her sexually that night after coming home from the bar, and it is exactly this thought that "makes life livable again," as Stein herself sagely stated. What astounds me most is that she would choose old Mr. Klangert out of all the world's men, not Rod Stewart or Mr. Percy or Milosz, but me. "Your correlations are poetry," she'd said, and it occurs to me only now that she really breathed out that last word-poetry, she'd said-and I think of this breath through the days and especially the nights, all the things we might have done to interfere with one another, had I not been so clueless.

I should instead have drawn her in, laced my fingers through her shiny brown bob cut, and touched my lips to hers. Would her round lenses have fogged? And would we have shared another laugh at this? I wonder what it all could have meant. I spend hours and hours constructing in my mind the life we were meant to have led instead of this one, in which I can't even recall her first name.

And as I sit staring at the sea, trying desperately to remember, the radio crackles. It makes the sound of scraping and scratching, and then a voice takes form to say a word with a long $A$ sound, and a moment later I realize the word is "Sailing," one of His songs. I grab the binoculars and glass the horizon all around for signs. There are none.

Later, from the east, a ship. His voice crows from the crackling radio:

I am sailing, I am sailing

Stormy waters to be near you

To be free

Lord, to be near you. Lord, to be free. 